\title{
Copper Electrodeposition from a Water-Containing Choline Chloride Based Deep Eutectic Solvent
}

\author{
P. Valverde, T.A. Green and S. Roy \\ Department of Chemical and Process Engineering, Strathclyde University, Glasgow, \\ Scotland G1 1XJ, UK
}

\begin{abstract}
This study investigated the effect of water on the physical and electrochemical properties of a choline chloride deep eutectic solvent (DES). Physical and electrochemical measurements were performed on the DES containing varying amounts of water. When the water content was increased from $1 \%$ to $15 \mathrm{wt} \%$, the viscosity and density declined while the conductivity increased significantly. Similarly, the limiting current for $\mathrm{Cu}$ reduction at $15 \mathrm{wt} \%$ of water was also found to be three times greater than the limiting current at $1 \mathrm{wt} \%$ of water. This latter effect could be mostly attributed to viscosity changes, but there was evidence of deviations from ideal Stokes-Einstein behaviour. These experimental results show that inclusion of water facilitates ion mobility, and generally results in improved electrochemical characteristics.
\end{abstract}

\section{Introduction}

Due to growing environmental regulations, alternatives to aqueous systems such as Ionic Liquids (ILs) are being examined for the electrodeposition of metals and alloys (1). In this work we have studied $\mathrm{Cu}$ deposition, a model electroplating system. Earlier studies have used chloroaluminates or hydrophobic anions to deposit this metal (2-8). Although these melts are useful for establishing reaction mechanisms or speciation of $\mathrm{Cu}$, they are not suitable for industrial plating applications due to their moisture sensitivity (9). Deep Eutectic Solvents (DESs) are a promising category of ILs since they are tolerant to water, stable under ambient conditions, and reasonably inexpensive $(10,11)$. However, they are hygroscopic and take up water unless special precautions are taken (1). Thus, in a real process, it is likely that the electroplating will proceed from water-containing electrolytes. However, for DESs to become exploitable, metal deposition from hydrated electrolytes requires further investigation. This study endeavours to establish a quantitative correlation between the physical properties and the electrochemical behaviour of $\mathrm{Cu}$ in a watercontaining DES.

\section{Experimental}

\section{Water Uptake by DESs}

'Ethaline' was prepared by mixing choline chloride $\left(\mathrm{C}_{5} \mathrm{H}_{14} \mathrm{NOCl}\right)$ and ethylene glycol $\left(\mathrm{C}_{2} \mathrm{H}_{6} \mathrm{O}_{2}\right)$ in a 1:2 molar ratio at $60^{\circ} \mathrm{C}$ until a transparent melt was formed. Both the choline chloride and ethylene glycol were not dried, so there was an intrinsic concentration of water in the ethaline. This was measured using a Hybrid Karl Fischer Titrator (MKH-700, Kem

This is a peer-reviewed, accepted author manuscript of the following research output Valverde Armas, P. E., Green, T., \& Roy, S. (2017). Copper electrodeposition from a water-containing choline chloride based deep eutectic solvent. ECS Transactions. (in press) 
Kyoto Electronics). Similarly, after dissolving the cupric chloride salt $\left(0.2 \mathrm{M} \mathrm{CuCl}_{2} \cdot 2 \mathrm{H}_{2} \mathrm{O}\right)$ in the electrolyte, the water content was measured by KF titration. Thereafter, in order to establish the absorption of water by the DES with time, the liquid was exposed to the air for over a month. From this electrolyte, samples were collected each week to be analysed.

\section{Physical Properties of Water-Containing Electrolytes}

In the next stage, the effect of water on physical properties such as density, viscosity and conductivity was performed. For these trials, samples were prepared containing 1,3 , 6,10 and $15 \mathrm{wt} \%$ water. The viscosity measurements of the water-containing samples were carried out using a DHR-2 Rheometer (TA Instruments) at $25{ }^{\circ} \mathrm{C}$. Sample density was determined using a specific gravity bottle (Fischer Scientific). Finally, the conductivity of the deep eutectic solvents was measured at room temperature using a calibrated InLab730 conductivity probe (Mettler Toledo).

\section{Electrochemical Behaviour Using Linear Polarization Scans}

Linear polarization scans were carried out to study the effect of water on the limiting current of $\mathrm{Cu}$ deposition. The voltammetric scans were carried out using a rotating disc electrode (RDE) controlled with PGSTAT101 potentiostat (Metrohm). The RDE was placed in a divided electrochemical cell separated by a sintered disk (Figure 1). Additionally, the cell had a jacket to maintain the temperature at $25^{\circ} \mathrm{C}$ with a thermostatic bath. A standard three electrode configuration was used. The working electrode was a Pt disc, the counter electrode was a Pt wire and the reference electrode was an Ag wire inserted in a fritted glass tube containing ethaline. This reference electrode was inserted inside a movable Luggin capillary so that the distance between the working and the reference electrode was maintained at $3 \mathrm{~mm}$. The potential was swept from the open circuit potential $+0.60 \mathrm{~V}$ and terminated at $-0.85 \mathrm{~V}$ with a scan rate of $5 \mathrm{mV} / \mathrm{s}$. The experiments were carried out at a rotation speed of $700 \mathrm{rpm}$.

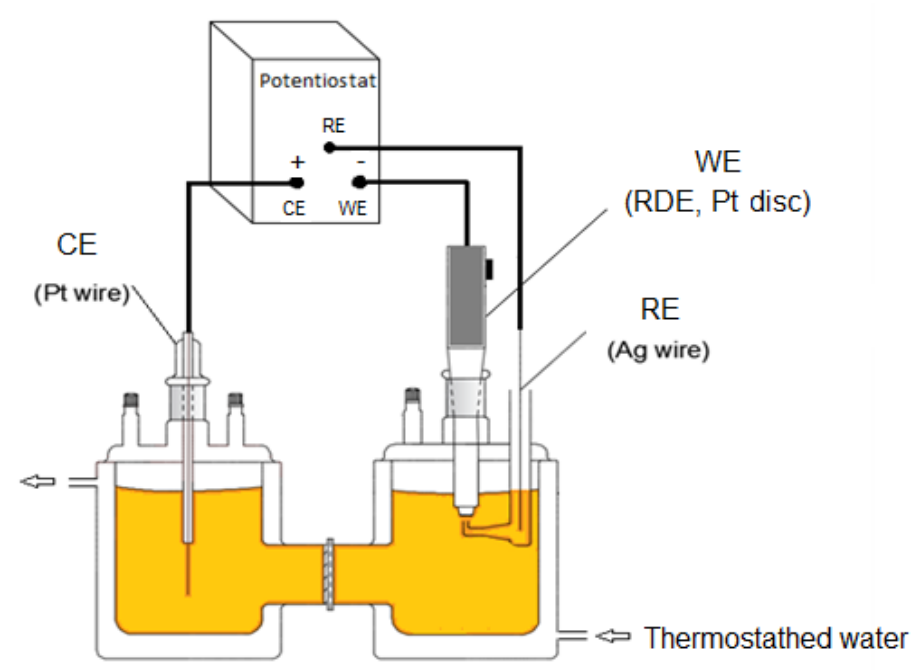

Figure 1. Schematic of the divided electrochemical glass cell used for linear polarisation and limiting current experiments. All the experiments were carried out at $25^{\circ} \mathrm{C}$ with a scan rate of $5 \mathrm{mV} / \mathrm{s}$. RDE experiments were performed at a rotation speed of $700 \mathrm{rpm}$.

[Type here] 


\section{Results}

The intrinsic water content of the ethaline melt was $1.00 \pm 0.09 \mathrm{wt} \%$. However, when $\mathrm{CuCl}_{2} \cdot 2 \mathrm{H}_{2} \mathrm{O}$ was dissolved in ethaline, the water content increased to $1.80 \pm 0.02 \mathrm{wt} \%$. This shows that $0.62 \mathrm{wt} \%$ of $\mathrm{H}_{2} \mathrm{O}$ is introduced from the waters of hydration of the metal salt. The uptake of water continued beyond this period and equilibrated at $28 \mathrm{wt} \%$ at the end of four months.

Table I summarizes the change in density, viscosity and conductivity of ethaline containing $0.20 \mathrm{M} \mathrm{CuCl}_{2} \cdot 2 \mathrm{H}_{2} \mathrm{O}$ with increasing water concentration. As shown in this table, the viscosity and density of the electrolyte decreased and the conductivity increased with increasing water content. Similar findings have been reported in earlier publications using a choline chloride/urea (reline) and choline chloride/chromium(III) chloride (12,13).

Table I. Effect of water on the viscosity, conductivity, density, and limiting currents for $\mathrm{Cu}$ reduction in $0.2 \mathrm{M} \mathrm{CuCl}_{2} \cdot 2 \mathrm{H}_{2} \mathrm{O}$ dissolved in ethaline.

\begin{tabular}{|c|c|c|c|c|c|c|c|c|c|c|}
\hline \multirow[t]{2}{*}{$\begin{array}{l}\text { Water } \\
\text { content } \\
\text { (wt } \%)\end{array}$} & \multirow[t]{2}{*}{$\begin{array}{c}\text { Dynamic } \\
\text { viscosity } \\
\eta \\
(\mathrm{Pa} \mathrm{s})\end{array}$} & \multirow[t]{2}{*}{$\begin{array}{c}\text { Kinematic } \\
\text { viscosity } \\
v \\
\left(\mathrm{~cm}^{2} \mathrm{~s}^{-1}\right)\end{array}$} & \multirow[t]{2}{*}{$\begin{array}{l}\text { Density } \\
\left(\mathrm{g} \mathrm{cm}^{-3}\right)\end{array}$} & \multirow[t]{2}{*}{$\begin{array}{c}\text { Conductivity } \\
\kappa \\
\left(\mathrm{mS} \mathrm{cm}^{-1}\right)\end{array}$} & \multicolumn{2}{|c|}{$\begin{array}{l}\text { Limiting } \\
\text { currents } \\
\left(\mathrm{mA} \mathrm{cm}^{-2}\right)\end{array}$} & \multicolumn{2}{|c|}{$\begin{array}{l}\text { Diffusion } \\
\text { coefficients } \\
\left(\times 10^{-7} \mathrm{~cm}^{2} \mathrm{~s}^{-1}\right) \\
\text { Equation } 3\end{array}$} & \multicolumn{2}{|c|}{$\begin{array}{c}\text { Equation } 4 \\
\left(\times 10^{-13}\right)\end{array}$} \\
\hline & & & & & $\mathrm{i}_{\text {Lim1 }}$ & $\mathrm{i}_{\mathrm{Lim} 2}$ & $\mathrm{D}_{\mathrm{Cu} 2+}$ & $\mathrm{D}_{\mathrm{Cu}}+$ & $\mathrm{D}_{\mathrm{Cu} 2+\eta}$ & $\mathrm{D}_{\mathrm{Cu}}+\eta$ \\
\hline 1 & 0.0473 & 0.419 & 1.127 & 7.95 & 3.0 & 2.8 & 1.29 & 1.16 & 6.10 & 5.49 \\
\hline 3 & 0.0436 & 0.387 & 1.126 & 9.53 & 4.3 & 2.9 & 2.16 & 1.20 & 9.42 & 5.23 \\
\hline 6 & 0.0345 & 0.307 & 1.123 & 10.2 & 4.4 & 4.1 & 2.11 & 1.90 & 7.28 & 6.56 \\
\hline 10 & 0.0223 & 0.199 & 1.119 & 11.6 & 6.4 & 6.1 & 3.33 & 3.10 & 7.43 & 6.91 \\
\hline 15 & 0.0151 & 0.137 & 1.098 & 15.3 & 9.0 & 9.1 & 5.07 & 5.09 & 7.66 & 7.69 \\
\hline
\end{tabular}

Fig. 2 shows the polarisation data for pure ethaline at a Pt electrode containing various amounts of water. These results show that the anodic decomposition potential of ethaline is hardly changed by the addition of water, but the cathodic process shows a more significant change. Increasing the water content from $1-15 \mathrm{wt} \%$ reduces the overall potential window by approximately $0.2 \mathrm{~V}$. While many ionic liquids can have their electrochemical window reduced significantly by the presence of even small amounts of water, this data shows that ethaline DES is tolerant to relatively high water contents.

Fig. 3 shows the polarization plot for $\mathrm{Cu}$ deposition at $\mathrm{Pt}$ electrode, at $25{ }^{\circ} \mathrm{C}$ and at a rotation speed of $700 \mathrm{rpm}$. The voltammograms showed two reduction waves: the first one corresponded to the reduction of $\mathrm{Cu}$ (II) to $\mathrm{Cu}(\mathrm{I})$ species (Equation 1), while the second wave resulted from the reduction of $\mathrm{Cu}(\mathrm{I})$ to $\mathrm{Cu}(0)$ (Equation 2). This type of behavior is common in a chloride-containing media (14) and it is due to the stabilisation of the $\mathrm{Cu}(\mathrm{I})$ oxidation state (15).

$$
\begin{array}{r}
\mathrm{CuCl}_{4}^{2-}+\mathrm{e}^{-} \rightarrow \mathrm{CuCl}_{2}^{-}+2 \mathrm{Cl}^{-} \\
\mathrm{CuCl}_{2}^{-}+\mathrm{e}^{-} \rightarrow \mathrm{Cu}+2 \mathrm{Cl}^{-}
\end{array}
$$

The effect of water upon the electrochemical reduction of $\mathrm{Cu}$ was a significant increase of both limiting currents ( $i_{\text {Lim } 1}$ and $i_{\text {Lim2 }}$ ) for the two reduction steps. These results show that water promotes the mass transport of $\mathrm{Cu}(\mathrm{II})$ and $\mathrm{Cu}(\mathrm{I})$ species to the electrode. Cyclic

[Type here] 
voltammetric studies (16) of the $\mathrm{CuCl}_{2}$-ethaline system also show an enhancement of peak currents with water content which is also consistent with enhanced mass transport.

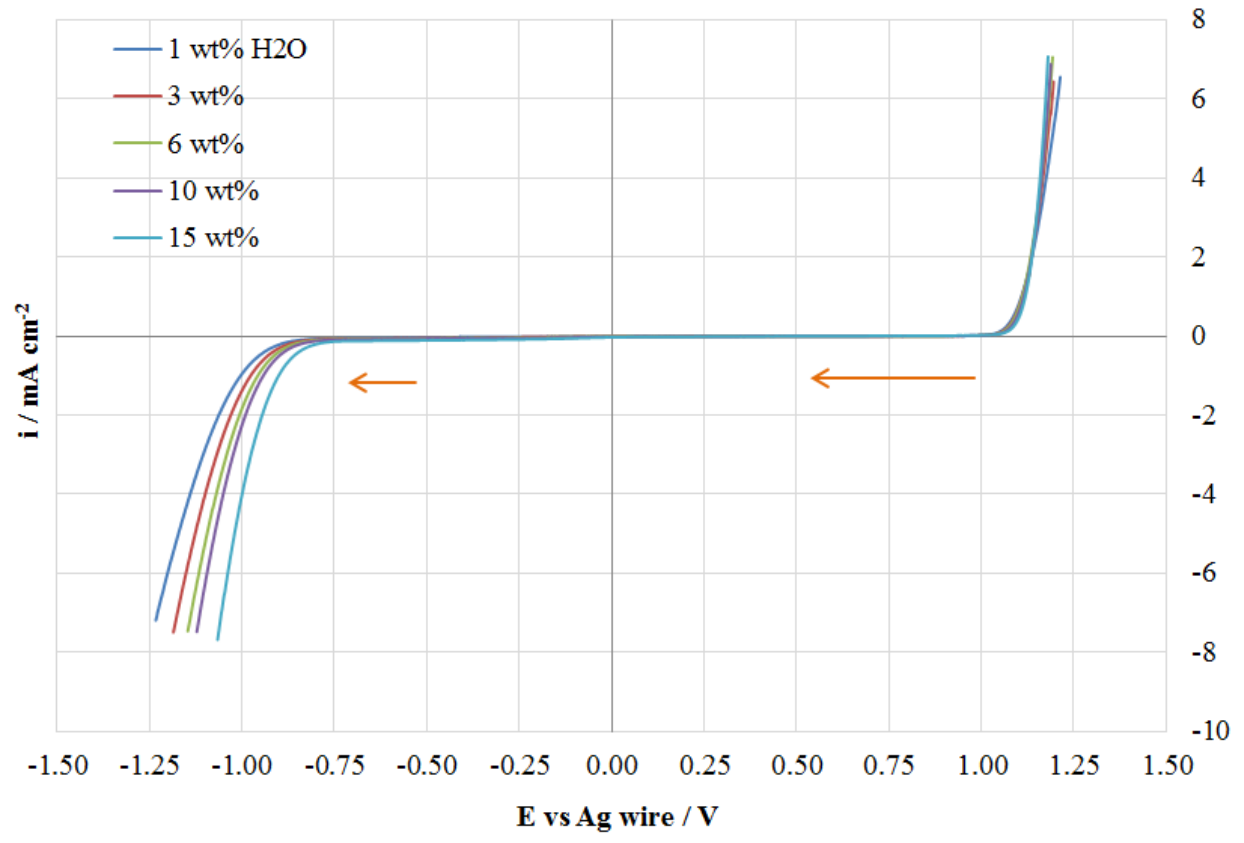

Figure 2. Voltammetry of pure ethaline with $1-15 \mathrm{wt} \%$ water. All the experiments were carried out on Pt electrode at $25^{\circ} \mathrm{C}$, a scan rate of $5 \mathrm{mV} / \mathrm{s}$ and with $\omega=700 \mathrm{rpm}$.

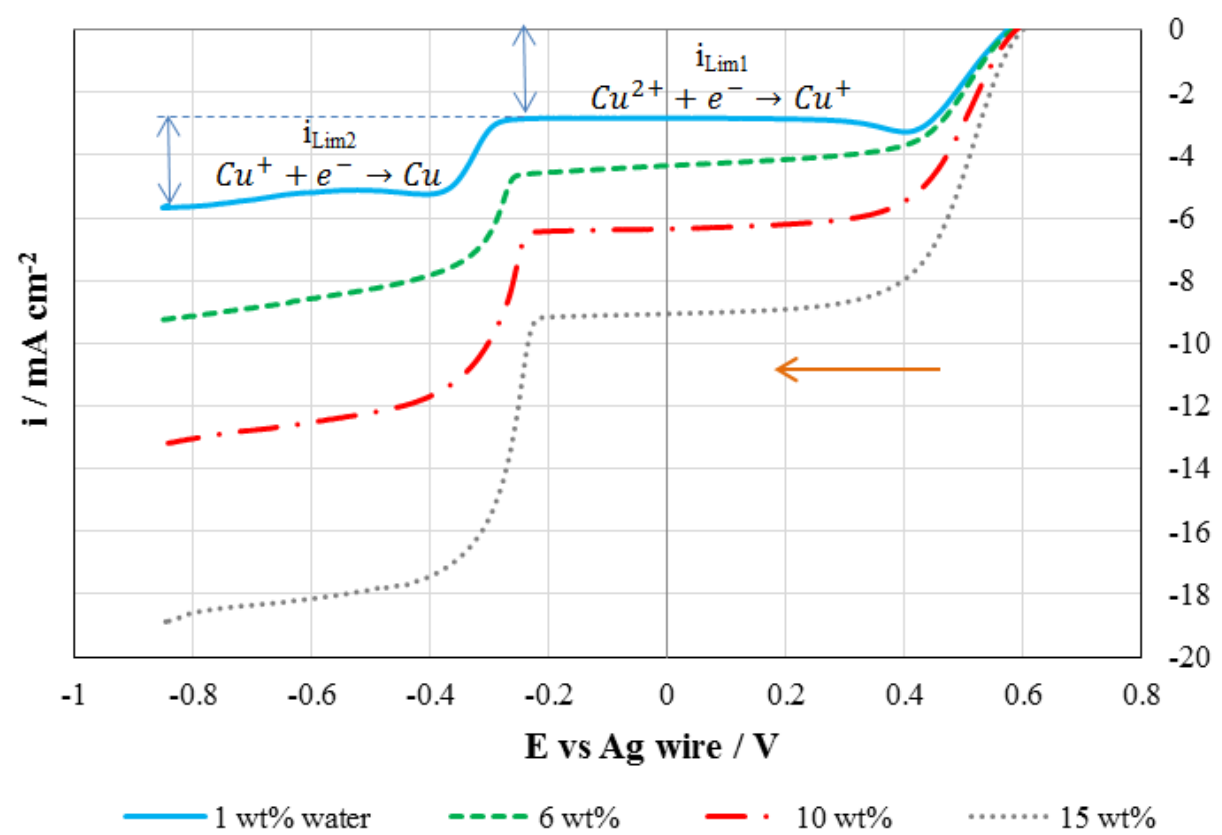

Figure 3. Polarisation data of $0.20 \mathrm{M} \mathrm{CuCl}_{2} \cdot 2 \mathrm{H}_{2} \mathrm{O}$ in ethaline at a Pt electrode at $25{ }^{\circ} \mathrm{C}$. The scan rate was $5 \mathrm{mV} \mathrm{s}^{-1}$ and $\omega=700 \mathrm{rpm}$. The amber arrow shows the direction of scan which commenced at an open circuit potential of $+0.6 \mathrm{~V}$.

[Type here] 


\section{Discussion}

The limiting current density, $\mathrm{i}_{\mathrm{Lim}}$, of an electrochemical reaction at a RDE is given by the Levich equation:

$$
\mathrm{i}_{\mathrm{Lim}}=0.62 \mathrm{nFAD}{ }^{2 / 3} v^{-1 / 6} \mathrm{C} \omega^{1 / 2}
$$

where $\mathrm{n}$ is the number of transferred electrons, $\mathrm{F}$ is the Faraday constant $\left(95485 \mathrm{C} \mathrm{mol}^{-1}\right)$, $\mathrm{A}$ is the area of electrode $\left(\mathrm{cm}^{2}\right), \mathrm{D}$ is the diffusion coefficient $\left(\mathrm{cm}^{2} \mathrm{~s}^{-1}\right), v$ is the kinematic viscosity $\left(\mathrm{cm}^{2} \mathrm{~s}^{-1}\right), \mathrm{C}$ is the concentration of bulk electrolyte $\left(\mathrm{mol} \mathrm{cm} \mathrm{cm}^{-3}\right)$, and $\omega$ represents the rotation speed $\left(\mathrm{rad} \mathrm{s}^{-1}\right)$. The values for diffusivity of the cuprous and cupric species calculated from the experimental data are presented in Table I.

The simplest explanation for the observed increase in diffusivity relates to the corresponding reduction in viscosity at higher water content. Applying the Stokes-Einstein relationship to the data in Table I, it can be seen that approximately $80 \%$ of the observed enhancement in diffusivity could be attributed to viscosity changes. The remaining effect may arise from other phenomena but there is also a possibility that the Stokes-Einstein equation is not valid for these particular ionic liquids (17). Normally, at constant temperature and constant ionic radii:

$$
\mathrm{D} \eta=\text { constant }
$$

where $\mathrm{D}$ is the diffusion coefficient of the $\mathrm{Cu}(\mathrm{II})$ and $\mathrm{Cu}(\mathrm{I})$ species and $\eta$ is dynamic viscosity. The data in Table I indicates that the product of $\mathrm{D}$ and $\eta$ is not constant over the range of water contents studies, indicating some significant deviations. Such deviations might arise if the ionic radius of the diffusing species was also varying, but previous studies (16) of the speciation of copper species remains unchanged until water content is $40 \mathrm{wt} \%$.

The effect of water content on DES properties has been studied previously (18-20). Reports of improved conductivity and reduced viscosity with water content have been rationalised in terms of conventional hole theory (18). With increasing water content, the hole size was found to increase resulting in higher ionic mobility and this is reflected in changes in both the viscosity and conductivity. An alternative explanation $(19,20)$ is that increasing water content causes ion pairs in the ionic liquid to dissociate further. This enhanced dissociation arises because water can form strong hydrogen bonds with anions in the melt. The overall effect of increased dissociation of ion pairs is an increase in conductivity and a reduction in viscosity. However, the current results do not allow any discrimination between the two models.

\section{Conclusions}

The effect of water on the density, viscosity and conductivity of the deep eutectic solvent along with the electrochemical behaviour of copper deposition was studied. It was found that increasing water content from $1 \%$ to $15 \mathrm{wt} \%$ caused a significant reduction in density and viscosity, but the electrical conductivity was considerably enhanced. The improved

[Type here] 
viscosity and conductivity may be attributable to an increased hole size or enhanced dissociation with increasing water content. Electrochemical polarization measurements showed that the electrochemical window on platinum electrodes was relatively insensitive to water content. Diffusion coefficients of $\mathrm{Cu}(\mathrm{II})$ and $\mathrm{Cu}(\mathrm{I})$ species, as determined from limiting current measurements also increased with water content. This enhanced diffusivity can be mostly attributed to viscosity changes in the deep eutectic solvent but there was also evidence for deviations from ideal Stokes-Einstein behaviour.

\section{Acknowledgments}

The authors would like to thank Secretariat of Higher Education, Science, Technology, and Innovation of Ecuador (SENESCYT) for funding this work. The European Cooperation in Science and Technology action (COST) MP1407 is acknowledged for providing training and networking opportunities.

\section{References}

1. F. Endres, D. MacFarlane and A. Abbott, Electrodeposition from Ionic Liquids, p. 83103, Wiley-VCH, Weinheim (2008).

2. K. Murase, K. Nitta, T. Hirato and Y. Awakura, J. Appl. Electrochem., 31, 1089 (2001).

3. H. Liu, Y. Liu and J. Li, Phys. Chem. Chem. Phys., 12, 1685 (2009).

4. H. Ohno, Electrochemical Aspects of Ionic Liquids, p. 129-150, John Wiley and Sons Inc., New Jersey (2011).

5. S. Kazemiabnavi, Z. Zhang, K. Thornton and S. Banerjee, J. Phys. Chem. B, 120, 5691 (2016).

6. Q. Li, J. Jiang, G. Li, W. Zhao, X. Zhao and T. Mu, Sci. China Chem., 59, 571 (2016).

7. Wu. X, E. Cooper and C. Angell, J. Phys. Chem. B, 107, 6170 (2003).

8. S. Abedin, M. Polleth, S. Meiss, J. Janek and F. Endres, Green Chem., 9, 549 (2007).

9. B. Tierney, W. Pitner, J. Mitchell, C. Hussey and G. Stafford. J. Electrochem. Soc., 145, 3110 (1998).

10. E. Smith, A.Abbott and K. Ryder, Chem. Rev., 114, 11060 (2014).

11. S. Ghosh and S.Roy Surf. Coat. Technol., 238, 165 (2014).

12. D. Shah and F. Mjalli, Phys. Chem. Chem. Phys., 16, 23900 (2014).

13. V. Protsenko, A. Kityk, D. Shaiderov and F. Danilov, J. Mol. Liq., 212, 716 (2015).

14. P. Sebastian, E. Valles and E. Gomez, Electrochim. Acta, 123, 285 (2014).

15. C. Leon and F. Walsh, Trans. Inst. Met. Fin., 81, 95 (2003).

16. P. De Vreese, N.R. Brooks, K. Hecke, L. Meervelt, E. Matthijs, K. Binnemans, and R. Deun, Inorg. Chem., 51, 4972 (2012).

17. J. O'M. Bockris and A.K.N. Reddy, Modern Electrochemistry, Vol 1., Plenum, New York (1970)

18. V. Protsenko, L. Bobrova, and F. Danilov, Ionics, 23, 637 (2017).

19. C. Du, B. Zhao, X. Chen, N. Birbilis, and H. Yang, Scientific Reports, 6, 1 (2016).

20. W. Li, Z. Zhang, B. Han, S. Hu, Y. Xie and G. Yang, J. Phys. Chem. B, 111, 6452 (2007).

[Type here] 